\title{
For richer, for poorer: China embraces global poverty reduction?
}

\author{
Gerald Chan
}

Correspondence:

gerald.chan@auckland.ac.nz

University of Auckland, Auckland,

New Zealand

\section{Springer}

\begin{abstract}
Has China embraced global poverty reduction? To what extent has it done so? China faces three paradoxes in trying to alleviate poverty: first, the country is on the whole getting richer, becoming one of the largest economies in the world, yet huge pockets of extreme poverty exist in the country. Second, it wants to be taken seriously as a responsible member of the international community. It would therefore like to be treated as a normal aid giver helping the poor in the developing world. Yet its own people are crying out loud for better social services at home. Third, while it wants to be respected by others in the world, it has been accused by other countries of ignoring, if not abusing, human rights in the Third World in its relentless search for natural resources, trade and investments. This paper aims to unravel these paradoxes by examining China's foreign aid and its adherence or otherwise to the UN Millennium Development Goals. In so doing, the paper assesses China's unilateral approach as well as its multilateral approach to poverty alleviation. It argues that China's overall approach has become more multilateral in nature but the change has been slow and incremental. Its influence in global poverty reduction, though increasing, is still limited.
\end{abstract}

Keywords: China; Poverty reduction; Foreign aid; Responsibility; Development

\section{Introduction}

China's economic growth in the past thirty-five years has dazzled many observers. Yet, in its path to development, the country has encountered many intriguing paradoxes. This paper examines three of these paradoxes in connection with the country's effort to alleviate poverty. The first one is that while the country is growing strong in aggregate terms, it is very weak in per capital terms. There are still many poor people in remote parts of the country and even on the outskirts of many big cities. The second paradox is that while China wants to be taken seriously as a responsible rising power in the world, it is being seen as irresponsible by others in many world affairs, especially in its relentless drive to search for natural resources, trade and investments around the globe, particularly in the Third World, while ignoring human rights abuses there. The third paradox is that while it wants to help the global poor, it is being hamstrung by the need to look after its own poor people at home, given its limited resources in relation to its huge population size. How do we unravel these paradoxes? What are their implications for China's effort to reduce poverty, globally and domestically?

\section{Paradox I: Is China a rich country or a poor country?}

China seems to be both: it is rich in aggregate terms, but poor in per capita terms. As of early 2014, China is the second largest economy in the world after the U.S., with Japan standing at number three. According to the International Monetary Fund

(C) 2015 Chan; licensee Springer. This is an Open Access article distributed under the terms of the Creative Commons Attribution License (http://creativecommons.org/licenses/by/4.0), which permits unrestricted use, distribution, and reproduction in any medium, provided the original work is properly credited. 
(IMF), in 2012 the GDP figures for these three countries in million U.S. dollars were 16,244,575; 8,221,015; and 5,960,269 respectively (IMF 2013). In November 2012 the Organisation for Economic Cooperation and Development (OECD) forecast that China would surpass the U.S. as the largest economy by 2016, measured in purchasing-powerparity terms (OECD 2013). On 30 April 2014 the Financial Times reported that the U.S. was on the brink of losing its status as the world's largest economy; it would slip behind China in 2014, based on World Bank statistics (Financial Times 2014b). According to the newspaper, the U.S. had been the global leader since overtaking the U.K. in 1872 (Financial Times 2014b). In terms of trade, Bloomberg reported that China surpassed the U.S. as the world's biggest trading nation in 2012 when measured by the sum of exports and imports (Bloomberg News 2013). In early 2013 the U.S. Commerce Department said that American exports and imports in 2012 totalled US\$3.82 trillion, while China's customs administration said that their country's total trade in 2012 amounted to US $\$ 3.87$ trillion. In addition, China has also become one of the most important investors around the world. According to the United Nations Conference on Trade and Development (UNCTAD), in 2012 the U.S. tops the list of the total amount of inward and outward foreign direct investment flows, amounting to US $\$ 167.62$ billion, while China was second with $\$ 121.08$ billion, and Hong Kong third with \$74.584 billion (UNCTAD 2013). The combined total of China and Hong Kong would then overtake the U.S., although the cross-border investment flows between China and Hong Kong are difficult to fathom. Above all, China has the largest foreign exchange reserves, close to US $\$ 4$ trillion by mid2014 and the amount has continued to grow over the years (Trading Economics 2014).

However, when measured in per capita terms, China is a very poor country. As of end-2013, its per capita income is US\$7,945 (UNDP 2013). Ranking in descending order of GPD per capita among countries of the world, this income is starkly low: its position is situated somewhere between 80 and $90^{\mathrm{a}}$, although it has moved steadily up the ranking order over the years. This ranking puts China in the company of such countries as Cuba, the Dominican Republic, Namibia, and Thailand. China is of course a country of great diversity, geographically and economically: The wealth gap is huge between major coastal cities such as Shanghai, Beijing, Tianjin, and Guangzhou and provinces in the central and western parts of the country. Even within many big cities, a huge wealth gap divides the urban centres and the nearby rural areas. A huge gap also exists between local residents and migrant workers in many cities.

Economic measurements and forecasts are one thing, whose accuracy is precarious for many well-known reasons, the quality of the living environment is quite another for China. The country is infamous for its poor environmental record. The cost of environmental damage to its economy, due to ill health or loss of production, has been estimated to range from three to ten per cent of its $\mathrm{GDP}^{\mathrm{b}}$. If the measurement of the quality of life is taken into account, then China is trailing a long way behind many countries in the world. For example, The Economist (2005) made a survey of the quality of life around the world in 2005, and ranked China 60 out of 111 countries surveyed; the top five countries were Ireland, Switzerland, Norway, Luxembourg, and Sweden. China trailed right behind Venezuela and was just ahead of Vietnam.

Because of China's regional diversity and its low per capita income, the World Bank still regards China as a developing country. Although new applications from China to the Bank for funding development projects in the country have been cut, the country still receives aid from it, mainly for some long-term ongoing projects that are close to completion. This situation poses serious implications for China in applying for and receiving foreign aid from other sources and, to a lesser extent, for it to extend its own aid to other developing countries.

\section{Paradox II: Is China a responsible country or not? ${ }^{c}$}

The answer to this question depends on how we gauge the idea of responsibility and who decides Chan $(2006,2014)$. There is apparently no single way to measure state responsibility in global affairs that would be acceptable to all concerned or to the absolute 
majority of states. This is so especially in international politics where anarchy is often regarded as the axiom. Anarchy, however, does not mean total chaos, as order exists in international society in the presence of diplomacy, rules, and international institutions, as Hedley Bull had cogently argued in his well-known book entitled The Anarchical Society (Bull 2002).

In the first place, responsibility is a nebulous concept. It can be viewed in so many ways, not least in terms of the difference between domestic and international responsibilities. Domestically, a government, in this case China, given its political system, can decide more or less within its own jurisdiction what constitutes domestic responsibility, although this is subject to some checks and balances by various actors, both inside and outside of the country, especially in such area as human rights. Internationally, as the world is being treated as an anarchical society, it is extremely difficult to find a universally acceptable, single authority to decide whether one country is globally responsible or not, and in what area, in what way, and at what time. The one organisation that comes close to being regarded as a credible authority in this respect is the United Nations, which in substance is an assembly of states, and whose authority still from time to time comes under the challenge of some its members, big or small. To China, multilateral organisations have become important forums for making major decisions affecting global security. At the global level, the Security Council of the United Nations is responsible for making decisions on peacekeeping and the maintenance of global security. At the regional level, major regional organisations are regarded by China as major instruments for making regional peace and stability, for example, the African Union, the Arab League, the Association of Southeast Asian Nations, and others. As a result of the different understandings of responsibility in world affairs, whether or not China is a responsible state in dealing with poverty reduction domestically and internationally is open to debate.

\section{Paradox III: Is China helping the global poor while neglecting its own destitute?}

No, not at least according to its official view, nor according to many outside observers, although domestic poverty remains a nagging problem for China. The reason why the answer is no can be gauged from the progress that China has made in tackling poverty at home. According to the United Nations Development Programme UNDP (2014a), China has lifted 500 million of its people out of abject poverty in the past three decades or so. Considering China's current population of around 1,353 million (UNDP 2014b), this means that more than a third of the people in China have been taken out of poverty, or roughly one fifteenth of humankind. This is no mean achievement. No wonder Chinese officials have often said that China is contributing to global poverty reduction by eliminating domestic poverty, treating China's own domestic problem as a global problem. However, the sheer size of China's population means that there are still many people suffering from the negative impact of poverty such as the lack of access to proper health care and education. In addition, the widening gulf between the rich and the poor in the country has continued to tarnish its record of poverty reduction at home.

The Guardian newspaper (Guardian 2014), citing the research done by Peking University, says that a third of China's wealth is held by one per cent of its citizens and the poorest quarter of Chinese citizens owns only one per cent of the country's wealth. The country's Gini coefficient, a widely used indicator of economic inequality, has grown sharply over the past two decades. (A Gini coefficient of zero represents absolute equality, while one represents absolute inequality). About twenty years ago, China's Gini coefficient for family net wealth was 0.45 , but by 2012 it had risen to 0.73 . In comparison, the U.S. has a Gini coefficient of 0.39, the U.K. 0.34, and Italy 0.32 .

The three paradoxes discussed above will continue to pose significant challenges to China in its engagement with the governance of poverty reduction around the world, in terms of the country's status and standing (rich or poor), its intentions and capabilities 
to deal with poverty alleviation (responsible or not), and its policy choices (global or domestic). How these three paradoxes are going to play out, individually and collectively, will affect the way China deals with poverty reduction in the world, the subject of attention in the rest of this paper.

\section{Living with paradoxes: How has China engaged global poverty reduction?}

China's engagement with global poverty reduction can best be seen from its involvement in multilateral coordination rather than through its unilateral or bilateral approach. Although unilateral or bilateral approach still forms an integral part of China's effort to reduce global poverty, it is in many ways geared towards enhancing China's national interests, at least seen by many aid recipients and aid donors. China's multilateral approach in this area, however, shows China's effort to become a concerned member of the aid community, taking collective action to deal with poverty and hunger worldwide. To examine China's multilateral approach, this paper focuses on three major international organisations and the South-South Programme.

The South-South Programme is a relatively new initiative that China and other emerging economies have initiated to help the poor in the Third World, making contributions as befitting rising economies and as responsible members of the international community. The three major international organisations in this study include the World Bank, the Organisation for Economic Cooperation and Development, and the United Nations Development Programme. The World Bank is the world's leading development bank whose mandate is to assist the development of those countries in need, mainly through project financing. The OECD is an organisation formed by the countries in the West, mainly in Europe, to help enhance the economic and social well-being of those countries in need. And the UNDP is a major development agency of the UN, well known for its work in promoting the UN Millennium Development Goals to help member countries to develop in a comprehensive way, with poverty reduction as the top priority.

\section{(a) The World Bank}

The World Bank was formed as the premier organisation to help countries to reconstruct and develop after the destruction caused by the Second World War, especially those in Europe. China joined the World Bank (and the IMF) in 1980. It has since benefited from the Bank's cheap loans for developing many projects in the initial phase of its opening up to the outside world, subsequent to the adoption of a reform policy in 1978. In addition, the Bank has transferred much technology and information to China to help the country to build up its infrastructural capacity. In 2007/08 the Bank extended US $\$ 1.5134$ billion to support ten development projects in the country, making a cumulative total of $\$ 43.688$ billion covering 296 projects (MOFA 2010).

On the other hand, in the past decade or so, China began to extend substantial bilateral aid to some African countries after a long pause caused by the Cultural Revolution in the 1960s. Many observers see this move as a way for China to secure valuable raw materials for its industries. Some observers in the West have accused China of turning a blind eye to the flagrant human-rights violations committed by some African governments, while the World Bank faces questions as to why it has continued to offer loans to a fast-growing China (Karns and Mingst 2010). The then President of the World Bank, Robert Zoellick, called on China to coordinate its support to the world's poor with the rest of the international community (read the West and the World Bank). China's increasing bilateral assistance extended to poor developing countries around the world with relatively few political strings attached has begun to pose a challenge to the World Bank, since these recipient countries can now turn to an alternative source of help without abiding by the stringent conditions of good governance set by multilateral financial institutions like the World Bank and the IMF. At the end of 2007 China said it would start donating to the World Bank's main concessional loans fund for poor countries by joining the Bank's International Development Association. In a visit to Beijing in September 
2013 by the Bank's President Jim Young Kim, China's Premier Li Keqiang pledged to boost cooperation with the Bank (Xinhua 2013).

Chinese economist Justin Yifu Lin's tenure as the Chief Economist and Senior VicePresident of the World Bank from 2008 to 2013 has added a new twist to the Bank's ideology. Lin's appointment marked a subtle shift, at least in small measures and in theoretical terms, of the Bank's free-market orthodoxy, as Lin, though trained at Chicago, is a firm believer in the important role played by the state, regarding it as the most important institution in the economy (New York Times 2008). His appointment was seen by some observers as a welcoming move long overdue. It was welcoming to many African countries which saw the development recipe handed down by the Bank, known otherwise as the 'Washington Consensus', as ill-conceived and condescending. It was long overdue as China has grown fast in the world economy during the past three decades or so. Robert Zoellick's remark in 2005, while serving as U.S. deputy secretary of state, that a rising China should become a responsible stakeholder in the global system, was a telling foresight (New York Times 2008). Lin's appointment, though attracting high publicity, represented a small change which might not mean a lot to the way the World Bank conducts its business (as usual). His stint of employment at the Bank, however, might have paved the way for China's increasing identification with and involvement in the Bank's activities.

One nagging problem that China has with the existing structure of the World Bank is the distribution of political power within the agency. According to a UN University report on global governance, a very large proportion of the voting rights in the World Bank are vested in the hands of a very small number of industrialised countries, the major shareholders, in terms of their paid-up capital (U.N. University 2001). As of November 2010 China held $2.85 \%$ of the Bank's shares and $2.78 \%$ of its voting rights, ranking sixth among the 186 member states of the Bank ${ }^{\mathrm{d}}$. (This distribution of voting rights has remained more or less the same up to mid-2014, as the Bank has failed to implement its policy change agreed to in April 2010 due to the blocking by the U.S. Congress for domestic reasons such as the country's sluggish economy and the attention and priority paid to local elections. A similar situation has occurred in the IMF). In contrast, a large number of developing countries and transitional economies are vested with a small proportion of the voting rights, even though they are the principal stakeholders, as interest payments by them provide a large part of the Bank's source of income.

Subsequent to the financial crisis of 2007-9, some major economies in the West encourage China to increase its financial contribution to the Bank to enhance the Bank's liquidity and hence its capacity to lend. China seems willing to do so, on the condition that its contribution could be reflected in its increasing voting power and its greater say in the Bank's decision making. In the World Bank Spring meeting in April 2010, the 186 member states agreed to boost the capital of the International Bank for Reconstruction and Development, one of the four major institutions making up the Bank, by US $\$ 86.2$ billion, of which $\$ 5.1$ billion were paid-in capital, in return for increasing the voting rights of developing and transition countries at the expense of Japan and some European countries. China's voting power (still subject to ratification of the changes by member countries, especially the U.S., as of mid-2014) has subsequently risen to a potential rate of $4.42 \%$, ranking third after the U.S. (15.85\%) and Japan (6.84\%) (see Figure 1). The combined voting rights of Germany, France and the UK would have been reduced to $11.5 \%$ from $13.08 \%$. But the (Group of 242011 ) developing countries ${ }^{\mathrm{e}}$ wished to have a system that would automatically revise the voting rights in accordance to transformations in the relative economic powers between the developed and developing worlds. Yan Fang of China University of Political Science and Law (in Beijing) even argues that 'China should at least be above Japan in terms of voting power', given the fact that China took over Japan to become the second-largest economy in the world in 2010 (Financial Times 2010; China Daily 2010; World Bank 2010b) ${ }^{\mathrm{f}}$. The next quota review, however, will not be due until 2015. It is expected that this 2015 review will be 


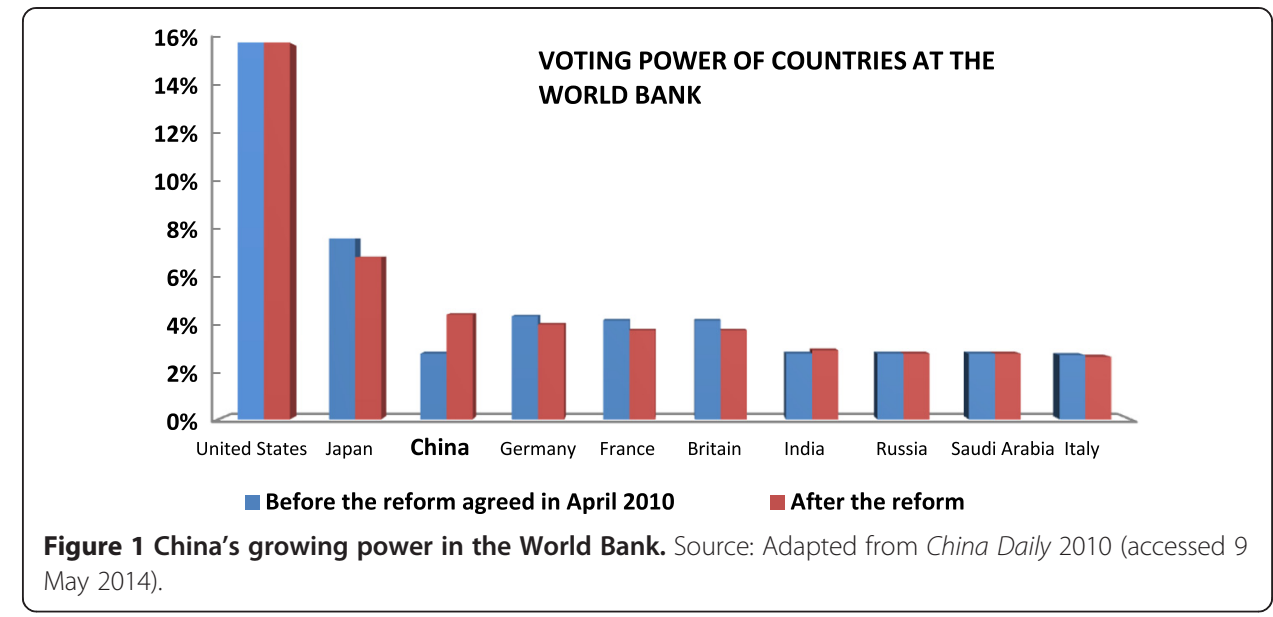

further pushed back as a result of the inconclusive implementation of the policy decision made in the earlier round of review in 2010.

\section{(b) The Organisation for Economic Cooperation and Development}

The OECD was formed in 1961 to promote cooperation and reconstruction among European economies in order to avoid the repeat of conflict and war in Europe. Its predecessor, the OEEC (Organisation for European Economic Cooperation) was formed in 1948 to coordinate with the U.S. Marshall Plan to help (Western) Europe reconstruct itself after the ravage of the Second World War. By convention, the OECD is a Western club, with members coming from liberal democracies. China is not a liberal democracy, and is therefore not strictly qualified to become a member, despite its increasing economic clout around the world. The OECD, however, wants to include China in its global economic policy deliberations, but find it difficult to include China as a member because of its lack of democratic credentials. China, on the other hand, wants to be involved in global economic policy making, but it wants to avoid being seen by fellow developing countries to be joining the club of the rich and so deserting the global poor. It also may want to avoid its hands being tied by the stringent rules of membership so as to maintain a greater degree of freedom acting outside of the group. But proper economic policy cannot be coordinated globally without the participation of China, as the country is the world's second biggest economy poised to become the largest.

A working relationship was eventually found to accommodate China in the OECD:⿱ . In October 1995 the OECD Council agreed to establish a programme of dialogue and cooperation with China. Since then, the OECD has contributed to policy reform in China by sharing its member countries' experiences in a wide range of areas, including trade and investment, science and technology, agriculture, environmental protection, education, corporate governance, and many more. In response, China has put its own policy experiences on the table for scrutiny and discussion by OECD member countries. For example, China's experiences in managing small- and medium-sized enterprises have been of use to the OECD in its outreach programme to help other developing countries. The OECD Council at Ministerial level adopted a resolution on 16 May 2007 to strengthen cooperation with China, as well as other emerging economies such as Brazil, India, Indonesia and South Africa, through a programme of enhanced engagement. Enhanced engagement is different from accession to the OECD, but it has the potential to lead to membership in future. China has been invited to participate as a regular observer to some OECD committees or working groups. In return, the country has helped the OECD in its global action by hosting OECD events in China and by participating in the OECD's regional activities in Asia.

At present China is one of the many non-member economies, including Taiwan, with which the OECD has working relationships. The political competition between China and 
Taiwan in various areas of global politics has spread to the OECD as well. For example, Taiwan has maintained a working relationship with the Development Assistance Committee (DAC), the foreign direct assistance arm of the OECD. Since the early 1990s, Taiwan and the European Bank of Reconstruction and Development have worked together to promote democracy and economic development in countries covered by the Bank's operations (Taipei Times 2011). Taiwan has been submitting reports of its foreign aid on an annual basis to the OECD since 2004, and the OECD has included aid statistics of Taiwan in its aid reports. Taiwan, under the name 'Chinese Taipei', is an observer to some of the committees of the OECD, including the Competition Committee (since 2001) and the Steel Committee (since 2005). As non-member economies, both Taiwan and China are competing for participation in committees and in other OECD sub-groups such as working parties and working groups. Both participated in high-level steel talks and in the special negotiating group on a ship-building agreement. Both eventually became observers of the Steel Committee in 2005, although China's status was a full participant whereas Taiwan was not. China has been regularly invited by the OECD to attend various committee meetings and events, whereas Taiwan's invitations are based on ad-hoc arrangements. Taiwan's desire to increase its activities in various committees as an observer has been dwarfed by China's opposition (WikiLeaks 2013). Efforts aimed at global poverty reduction are sometimes compromised by political considerations.

\section{(c) The United Nations Development Programme}

The UNDP is one of the largest agencies of the UN system, in terms of its aid budget. China began to participate in its activities starting from 1972, a year after the country became a member of the United Nations. The UNDP is one of the earliest UN agencies to start work in China, in fact in 1979, when China began to open up and to reform under former leader Deng Xiaoping. Among the various programmes that the UNDP works in China is poverty alleviation. The UNDP often cites the success made by China in lifting 500 million people out of extreme poverty in the past thirty years or so as a major achievement (UNDP 2014a). China works with the UNDP to pass on China's experience and technological know-how to other developing countries under the so-called South-South cooperation, in an agreement signed between China and the UNDP in 2010. This was the first such agreement that China signed with a partner, multilaterally or bilaterally (UNDP 2014c), in a trilateral arrangement that involves aid recipients as the third party. Such trilateral programmes have become a popular form of cooperation in recent years in the global aid community. China supports the achievement of the eight UN Millennium Development Goals, the first and foremost goal being poverty reduction around the world.

In August 2014 UN Secretary-General Ban Ki-moon set up an Independent Expert Advisory Group on the Data Revolution for Sustainable Development. The purpose is to advise him on the future development agenda beyond 2015 to succeed the UN Millennium Goals. The advisory group consists of twenty-four experts drawn from civil society, the private sector, academics, governments and international organisations (UN News Centre 2014). The fact that one of the two co-chairs of the group is Robin Li of China suggests that China is supportive of the UN and the UNDP in framing the future global development programme.

\section{(d) South-South Cooperation}

China has started to push forth this kind of cooperation, not only with the UNDP, but also with other emerging economies, in formulating coordinated effort to help the Third World. The country published its first white paper on foreign aid in April 2011. In the same year India announced that the Indian Agency for Partnership in Development would oversee an aid budget of over US\$11 billion in the next five to seven years (Guardian Weekly 2011). All the aid policies of these emerging economies share a similar aim of boosting South-South cooperation. For example, China's aid aims to establish 
mutual help between developing countries; Brazil's aid programme is framed to achieve solidarity and cooperation among Latin-American countries and Portuguese-speaking countries in Africa; Russia, 're-emerging' from the demise of the Soviet Union, a major donor to socialist countries before, says it wants to be a good neighbour by supporting low-income countries (Guardian Weekly 2011).

At a BRICS summit meeting held in Durban in March 2013, leaders agreed to set up a collective development fund, known to some observers as the BRICS bank, to help the Third World poor, and in addition a financial reserve fund, modelled upon the Chiang Mai Initiative Multilateralisation (CMIM) (Chan 2012), to support developing countries if they face emergency financial difficulties. It is reported that the BRICS bank will have an initial capital of US\$50 billion; and the reserve fund will pool together $\$ 100$ billion, with $\$ 41$ billion from China, $\$ 18$ billion each from Russia, India and Brazil, and $\$ 5$ billion from South Africa (Bretton Woods Project 2013). It is also reported that, Chen Yuan, the Governor of the state-owned China Development Bank for fifteen years, would leave his post to spearhead the organising of the BRICS bank (Caixin 2013).

At the BRICS summit held in Fortaleza, Brazil, in July 2014, the group decided to set up the new development bank in Shanghai, with an initial capital of US\$50 billion, rising to $\$ 100$ billion and with a separate $\$ 100$ billion Contingent Reserve Arrangement. India will assume the presidency of the bank for the first six years, followed by rotating terms for Brazil and Russia. The BRICS countries contain $40 \%$ of the world's population and account for $20 \%$ of global economic output. China alone represents $70 \%$ of the collective GNP of the BRICS (International New York Times 2014).

The setting up of the BRICS bank is seen by many observers as a rivalry to the World Bank and the IMF, but the World Bank President Dr Jim Yong Kim has a more considered view. He says that new entrants like the BRICS bank will help the World Bank battle poverty and spur growth rather than threaten its position. He says that the need for new investments in infrastructure would be massive, with such funding needs in developing countries estimated at US\$1 trillion a year, while the World Bank could only offer US\$60 billion in 2013 (South China Morning Post 2014).

Drawing on the favourable reception of CMIM by member states, in April 2014 the Asian Development Bank called for the establishment of a similar scheme to deal with natural disasters in the Asian region (Interaksyon 2014). At an APEC summit held in Bali, Indonesia, in October 2013, Chinese President Xi Jinping proposed the establishment of an Asian Infrastructural Investment Bank (AIIB) to integrate the economies of Asian countries. The suggested paid-up capital would be US $\$ 100$ billion, with China making a major contribution (Financial Times 2014d). As of mid-2014, twenty-two countries, including several wealthy states in the Middle East, have shown interest in the multilateral lender. This suggested amount is slightly less than two thirds that of the Asian Development Bank (ADB). Although the AIIB is still on paper, it seems to have the future potential of taking away some of the functions and influence of the ADB, where Japan and the U.S. are major shareholders, holding respectively $15.7 \%$ and $15.6 \%$ of the shares of the ADB, with China trailing far behind with $5.47 \%$ (Bloomberg News 2014). The ADB estimates that Asia will need $\$ 800$ billion a year of infrastructure investment between 2014 and 2020, but it can only lend $\$ 10$ billion a year for infrastructure, theoretically providing scope for other entities such as the AIIB to contribute. Takehido Nakao, the President of the ADB, has cautiously welcomed China's proposal to establish the AIIB (Financial Times 2014d).

Another recent attempt by China to enhance its multilateral approach to South-South cooperation is the launch in May 2014 of an investment plan called 'Africa China Growing Together' fund. The fund, established by China and the African Development Bank, is worth US $\$ 2$ billion. It was set up subsequent to a high-profile visit by Chinese Premier Li Keqiang to four African countries (Ethiopia, Nigeria, Angola, and Kenya) earlier in the month. This investment is seen as a change of tack by China from a bilateral approach 
in the past to dealing with development and poverty reduction in Africa to a more transparent, multilateral way (Financial Times 2014a). The amount of the fund, however, is dwarfed by China's US $\$ 27.7$ billion worth of investments across Africa (Wall Street Journal 2014).

Through working with the three major international organisations (the World Bank, the OECD, and the UNDP) discussed above and with other emerging economies and developing countries in South-South cooperation, China has demonstrated that it is charting a course for itself to become a member of the international community doing its part in poverty alleviation, both domestically and internationally. It main focus is to help its own poor people as well as those in the Third World. It coordinates such work with countries rich or emerging, organisations that are run by the developed West or by the developing world. Its draw card is its huge foreign exchange reserves, reaching an all-time high of nearly US\$4 trillion in the first quarter of 2014, according to the Financial Times (2014c). Part of this reserve could potentially be used to help the poor while financing its economic growth. In some ways, China has beaten a new path in global poverty reduction. Apart from working with some traditional aid donors like those in the OECD countries, it has also gradually engaged with some new international aid agencies and emerging economies to coordinate an increasing flow of foreign aid from these economies.

\section{Conclusions}

This paper sets out to ask this question: Has China embraced global poverty reduction? Judging from the fact that the People's Republic of China was born a poor country in 1949 and has since struggled to become a relatively well-off society (xiao kang or 小康), the fact that it has successfully lifted some 500 million people out of abject poverty in the past thirty years or so, and the fact that it has identified itself with the developing world and has taken concrete steps to boost South-South cooperation, it does seem that China has embraced global poverty reduction. This is so, despite the fact that it has continued to face the three major paradoxes, as discussed in the early part of the paper. Whether China is a rich country or a poor one, whether it is responsible or not, and whether it has struck a proper balance between helping its own poor people and those outside, it does seem that China is increasingly doing its part to alleviate poverty. These paradoxes sometimes present distractions to China's attention to global poverty reduction and put obstacles across its path to slow down its assistance to the developing world, but they have not prevented China from staying on its developmental course. To what extent China embraces global poverty reduction becomes a tricky question. How to measure China's role in this respect is by no means easy. As China wants to be seen as a responsible rising power, it is safe to assume that the country wants to engage or at least to be seen to be engaging with global poverty reduction. The extent to which it does so can then become an issue of assessing China's altruistic behaviour and its capability to help others, an issue that deserves further enquiry. At least at present China is increasingly involved in global poverty reduction.

\section{Endnotes}

${ }^{\text {a }}$ Whether it is by IMF ranking, or by that of the World Bank, or by the UN.

${ }^{\mathrm{b}}$ The Guardian (2010) quotes a figure of 3\%, while the New York Times (2013) 3.5\%, the World Bank (2013) 4.3\%, and the China Daily (2006) 10\%.

${ }^{\mathrm{c}} \mathrm{A}$ more elaborative analysis can be found in Chan (2006), chapter 2, pp. 33-62. See also Gao (2013).

${ }^{\mathrm{d}}$ See MOFA (2010). For a full table of the subscriptions and voting power of the 186 member countries of the International Bank for Reconstruction and Development as of 1 November 2010, see World Bank (2010a). 
${ }^{\mathrm{e}}$ Its official name is the Intergovernmental Group of Twenty-Four on International Monetary Affairs and Development (G-24) and was established in 1971. China is an observer country. Accessed July 12, 2011, at http://www.g24.org.

${ }^{\mathrm{f}}$ The voting powers of the member states of the IBRD before the reform are shown in http://siteresources.worldbank.org/BODINT/Resources/278027-1215524804501/IBRDCountryVotingTable.pdf (accessed 27 April 2010). The quote is from Xin, 'China gains more say in World Bank'. China is not a formal member of the G24 but has been a 'special invitee' since 1981 (http://www.g24.org).

${ }^{\mathrm{g}}$ The rest of this paragraph draws its sources from the OECD (2014).

\section{Acknowledgements}

This paper was presented as a keynote speech at 'Envisioning South-South relations \& development: past, present, and futures,' an inaugural conference of a new Springeropen journal Bandung: Journal of the Global South, held on 20-21 May 2014 at the City University of Hong Kong. I am grateful to Dr Pak Nung Wong, the Editor-in-Chief, for his kind invitation to give the speech and to the conference participants for their comments and criticisms. I am also grateful to two anonymous reviewers for their helpful suggestions to tidy up and to strengthen the arguments in the paper.

Received: 7 November 2014 Accepted: 10 November 2014

Published online: 11 June 2015

References

Bloomberg News. 2013. 'China eclipses U.S. as biggest trading nation,' Bloomberg News, 11 February. http:// www.bloomberg.com/news/2013-02-09/china-passes-u-s-to-become-the-world-s-biggest-trading-nation.html (accessed 26 December 2013).

Bloomberg News. 2014. 'China's $\$ 50$ billion Asia bank snubs Japan, India,' 12 May. http://www.bloomberg.com/ news/2014-05-11/china-s-50-billion-asia-bank-snubs-japan-india-in-power-push.html (accessed 15 May 2014).

Bretton Woods Project. 2013. BRICS challenge IFIs out of the frying pan into the fire. 8 April, www.brettonwoodsproject.org/ art-572264 (accessed 18 April 2013).

Bull, Hedley. 2002. The anarchical society: a study of order in world politics. New York: Columbia University Press.

Caixin. 2013. Chen Yuan to leave CDB and head BRICs development bank. http://finance.caixin.com/2013-04-11/100512815.html (accessed 18 April 2013).

Chan, Gerald. 2006. China's compliance in global affairs: trade, arms control, environmental protection, human rights. Singapore: World Scientific.

Chan, Gerald. 2012. China's response to the global financial crisis and its regional leadership in East Asia. Asia Europe Journal 9(Nos. 2-4): 197-209.

Chan, Gerald. 2014. Capturing China's international identity: social evolution and its missing links. Chinese Journal of International Politics 7(2): 261-81.

China Daily. 2006. http://www.chinadaily.com.cn/china/2006-06/06/content_609350.htm (accessed 24 May 2014).

China Daily. 2010. China gains more say in World Bank. 27 April, http://www.chinadaily.com.cn/business/2010-04/ 27/content_9778666.htm (accessed 9 May 2014).

Economist. 2005. http://www.economist.com/media/pdf/QUALITY_OF_LIFE.pdf (accessed 24 May 2014).

Financial Times. 2010. World Bank wins rise in capital. 25 April, http://www.ft.com/cms/s/0/c8b8937e-5095-11df-bc8600144feab49a.html (accessed 26 April 2010).

Financial Times. 2014a. China changes tack on Africa with bn multilateral investment. 18 May, http://www.ft.com/intl/cms/s/ 0/d1bd7f3a-de84-11e3-b46b-00144feabdc0.htm|\#axzz32ldH9jnH (accessed 22 May 2014).

Financial Times. 2014b. China poised to pass US as world's leading economic power this year. Internet ed., 30 April.

Financial Times. 2014c. China's foreign exchange reserves near record \$4tn. 15 April (accessed 24 May 2014).

Financial Times. 2014d. China expands plans for World Bank rival. 24 June (accessed 29 June 2014).

Gao, Xiang. 2013. China as a "responsible power": altruistic, ambitious or ambiguous. International Journal of China Studies 4(3 Supplement): 405-38.

Group of 24. http://www.g24.org (accessed 12 July 2011).

Guardian. 2010. http://www.theguardian.com/world/2010/dec/28/china-130-bn-economic-growth (accessed 27 December 2013).

Guardian. 2014. China gets richer but more unequal. 28 July, http://www.theguardian.com/world/2014/jul/28/china-moreunequal-richer (accessed 5 September 2014).

Guardian Weekly. 2011. 34.

IMF. 2013. Report for selected countries and subjects. world economic outlook database, October, data and statistics, IMF, online (accessed 26 December 2013).

Interaksyon. 2014. Disaster fund similar to Chiang Mai Initiative needed in Asia - ADB report. http://www.interaksyon.com/ business/85261/disaster-fund-similar-to-chiang-mai-initiative-needed-in-asia__adb-report (accessed 8 May 2014).

International New York Times. 2014. A challenge from the BRICS. editorial, 24 July, p. 6.

Karns, Margaret P, and Karen A Mingst. 2010. International organizations: the politics and processes of global governance. Boulder, CO: Lynne Rienner Publishers.

MOFA. (2010). Ministry of Foreign Affairs, PRC, http://www.fmprc.gov.cn/chn/pds/gjhdq/gjhdqzz/lhg_18/ (accessed 23 December 2010).

New York Times. 2008. A challenge from within for the World Bank. 25 January, http://www.nytimes.com/2008/01/25/world/ asia/25iht-letter26.4.9508142.html (accessed 18 February 2011).

New York Times. 2013. http://www.nytimes.com/2013/03/30/world/asia/cost-of-environmental-degradation-in-china-isgrowing.html?_r=0 (accessed 27 December 2013). 
OECD. (2013). 'Balance of economic power will shift dramatically over the next 50 years, says OECD,' http://www.oecd.org/ newsroom/balanceofeconomicpowerwillshiftdramaticallyoverthenext50yearssaysoecd.htm (accessed 26 December 2013).

OECD. (2014). http://www.oecd.org/china/chinaandtheoecd.htm (accessed 8 May 2014).

South China Morning Post. 2014. Kim backs launch of BRICS bank. 9 July, p. B1.

Taipei Times. 2011. Taiwan renews commitment to European funds. 7 April, p. 3.

Trading Economics. 2014. China's foreign exchange reserves, 1980-2014. http://www.tradingeconomics.com/china/foreign-exchange-reserves (accessed 4 September 2014).

UNCTAD. (2013). Inward and outward foreign direct investment flows, annual, 1970-2012, http://unctadstat.unctad.org/TableViewer/tableView.aspx (assessed 27 December 2013).

UNDP. (2013). http://www.cn.undp.org/content/china/en/home/ourwork/povertyreduction/overview.html (accessed 25 December 2013).

UNDP. 2014a. About UNDP in China. http://www.cn.undp.org/content/china/en/home/operations/about_undp.html (accessed 8 May 2014).

UNDP. 2014b. Overview. http://www.cn.undp.org/content/china/en/home/ourwork/povertyreduction/overview.html (accessed 9 May 2014).

UNDP. 2014c. South-South cooperation. http://www.cn.undp.org/content/china/en/home/ourwork/south-south-cooperation/ overview.html (accessed 8 May 2014).

UN News Centre. 2014. Data revolution advisory group named by the UN Secretary-General. 29 August, http:// www.un.org/apps/news/story.asp?NewsID=48594\#.VAl1zk1WFjo (accessed 5 September 2014).

U.N. University. 2001. U.N. University Report on Global Governance. 2 May, www.sovereignty.net/center/unureport.html (accessed 28 December 2010).

Wall Street Journal. 2014. China launches billion African development fund investment through African Development Bank to guarantee ethics, transparency. 22 May.

WikiLeaks. 2013. China and Taiwan at the OECD: hardball over soft. U.S. Embassy diplomatic cables, http://dazzlepod.com/ cable/06PARIS2868/ (accessed 13 May 2013).

World Bank. 2010a. http://siteresources.worldbank.org/BODINT/Resources/278027-1215524804501/IBRDCountry VotingTable.pdf (accessed 23 December 2010).

World Bank. 2010b. World Bank reforms voting powers, gets $\$ 86$ billion boost. Press Release No: 2010/363/EXT, 25 April, http://web.worldbank.org/WBSITE/EXTERNAL/NEWS/0, contentMDK:22556045 pagePK:34370 piPK:34424 theSitePK:4607,00.html (accessed 27 April 2010).

World Bank. 2013. http:/web.worldbank.org/WBSITE/EXTERNAL/COUNTRIES/EASTASIAPACIFICEXT/EXTEAPREGTOPENVIRONMENT/ 0 contentMDK:21252897 pagePK:34004173 piPK:34003707 theSitePK:502886,00.html (accessed 27 December 2013),

Xinhua. 2013. Li: China to deepen cooperation with World Bank. Xinhua news, http://news.xinhuanet.com/english/video/ 2013-09/18/c_132730219.htm (accessed 2 February 2014). 